\title{
Kajian Teori Public Trust Doctrine Dalam Kasus Lingkungan: Studi Kasus UU Minerba Baru
}

\author{
Ardianto Budi Rahmawan ${ }^{1}$ dan Kenny Cetera ${ }^{2}$
}

\begin{abstract}
Abstrak
Public Trust Doctrine (PTD) mengatur bahwa pemerintah wajib mengurus SDA untuk kepentingan publik meskipun akses atas Sumber Daya Alam (SDA) tersebut telah diberikan kepada pihak tertentu. Tulisan ini hendak membahas konstruksi PTD dalam hukum Indonesia dan menggunakan PTD untuk menganalisis konstitusionalitas UU Minerba Baru (UUMB), yang resmi disahkan pada tanggal 12 Mei 2020. Banyak pihak menyayangkan pengesahan ini karena dianggap mendukung eksploitasi minerba yang tidak berkelanjutan dan mengancam kesejahteraan masyarakat di sekitar wilayah tambang. Penulisan artikel ini akan menggunakan metode penelitian yuridis normatif dengan menggunakan sumber bahan sekunder berupa peraturan perundang-undangan dan putusan-putusan Mahkamah Konstitusi (MK). Hasil analisis menunjukkan eksistensi PTD pada Pasal 33 ayat (3) Konstitusi, yang dapat diaplikasikan apabila: SDA tersebut memiliki peranan penting dalam menguasai hajat hidup orang banyak dan pengaturan SDA tersebut dalam UU memenuhi unsur "sebesar-besar kemakmuran rakyat." Namun, analisis pada Pasal 22, 169A ayat (1), dan 169B ayat (5) UUMB menunjukkan adanya ketidakselarasan dengan konsep PTD.
\end{abstract}

Kata Kunci: Public Trust Doctrine, Sumber Daya Alam (SDA), UU Minerba.

\section{Abstract}

The Public Trust Doctrine (PTD) regulates that the government should prioritize public interest even if the access to the natural resources (SDA) has been given to individuals or parties. The research will discuss PTD construction in Indonesian law and use PTD to analyze Mineral and Coal Law constitutionality that has been enacted on May 12, 2020. Many parties regret the enactment of this law because the law tends to promote unsustainable exploitation and threatens public welfare who live nearby the mines. This research will be conducted by using normative juridical method and secondary resources such as law and constitutional court award (MK). The result indicates that PTD existence on Article $33 \mathrm{sec}$ (3) Indonesia constitution is applicable if: SDA has a crucial role in public sphere and SDA regulation fulfills the elements "to the fullest of public welfare". Yet, our analysis on article 22, article 169A sec (1), and article 169B sec (5) of Mineral and Coal Law shows incoherence with the concept of PTD. Keywords: Public Trust Doctrine, Natural Resources, Mining Law

\footnotetext{
${ }^{1}$ Penulis adalah Dosen Hukum Administrasi Negara Fakultas Hukum Universitas Gadjah Mada.

${ }^{2}$ Penulis adalah Analis Legalitas Hutan di World Resources Institute Indonesia (WRI Indonesia).
} 


\section{Pendahuluan}

Public Trust Doctrine (PTD) adalah doktrin yang berasal dari zaman romawi dan berkembang di beberapa negara dengan menunjukkan kepentingan publik yang harus diperhatikan dalam pengelolaan SDA. Doktrin PTD banyak berkembang dalam berbagai sengketa lingkungan dan SDA di Amerika Serikat karena konsep penerapannya dianggap sebagai terobosan baru dalam hukum lingkungan. ${ }^{3}$ Menurut Richard Frank, PTD merupakan doktrin yang menjadi dasar untuk hukum lingkungan dan manajemen SDA, yang menunjukkan adanya kewajiban pemerintah untuk menjaga dan melindungi kepentingan publik atas pengelolaan SDA.

Dalam kasus Juliana v. United States, sekelompok remaja mengajukan gugatan terhadap pemerintah Amerika Serikat karena dianggap gagal untuk mengurangi dampak emisi gas rumah kaca. ${ }^{4}$ Pemerintah juga dianggap melanggar hak konstitusional kaum remaja untuk kehidupan yang layak dan kewajiban pemerintah untuk menjaga beberapa SDA sebagai "wali" (trust) dari rakyat dan generasi mendatang. Anak-anak muda ini menuntut adanya deklarasi terbuka bah- wa hak konstitusional mereka dilanggar dan pemerintah harus mengembangkan rencana nyata untuk mengurangi emisi.

Meskipun konsep PTD lebih banyak berkembang pada negara dengan sistem common law seperti Amerika Serikat, beberapa prinsip yang terkandung di dalam PTD memiliki relevansi dalam konteks hukum Indonesia. Daud Silalahi menjelaskan bahwa konsep PTD adalah akar dari perundang-undangan lingkungan di Indonesia. ${ }^{5}$ Konsep PTD erat kaitannya dengan prinsip common ownership dan kembali pada esensi awal dimana lingkungan, secara sah merupakan milik bersama, termasuk di antaranya adalah air, laut, tanah, udara dan sekitarnya. Selain itu, dimensi kepemilikan publik atas SDA tercermin pada Pasal 33 ayat (3) UUD Tahun 1945, yang berbunyi: “Bumi dan Air dan Kekayaan alam yang terkandung didalamnya dikuasai oleh negara dan dipergunakan untuk sebesar-besarnya kemakmuran rakyat."

Artikel ini bertujuan untuk menelaah potensi penggunaan Teori PTD dalam dinamika hukum lingkungan di Indonesia. Penulis melihat Undang-Undang Nomor

\footnotetext{
${ }^{3}$ C. Solomon. "The Newest Legal Tool to Fight Climate Change is as Old Ancient Rome", Outside, 2016, https://www.outsideonline.com/2083441/newest-legal-tool-fight-climate-change-old-ancient-rome, diakses tanggal 16 Juli 2020.

4 Sabin Center for Climate Change Law."Juliana v. United States - Climate Change Litigation." http://climatecasechart.com/case/juliana-v-united-states/, diakses 1 Juli. 2020.

${ }^{5}$ M. Daud Silalahi, Pengaturan Hukum Sumber Daya Air dan Lingkungan Hidup di Indonesia, (Bandung: Alumni, 2002), hlm. 9.
} 
3 Tahun 2020 tentang Perubahan atas Undang-Undang Nomor 4 Tahun 2009 tentang Pertambangan Mineral dan Batubara (UUMB) cukup relevan sebagai studi kasus untuk memperkirakan skenario implementasi teori PTD di Indonesia.

Pada tanggal 12 Mei 2020, rapat paripurna DPR RI secara resmi mengesahkan UUMB. Keluarnya UUMB ini memicu polemik karena proses pengesahannya yang bisa dibilang instan dan minim partisipasi publik. ${ }^{6}$ UUMB diterbitkan di tengah pandemi COVID-19 sehingga dianggap memanfaatkan momentum untuk menghindar dan demonstrasi di masa Pembatasan Sosial Berskala Besar (PSBB). Selain itu, ada kekhawatiran bahwa UUMB dibuat untuk "menjamin" konsesi pertambangan korporat besar, tidak memihak masyarakat sekitar pertambangan dan berpotensi memberikan dampak lingkungan yang masif. ${ }^{7}$

Bukti nyata dampak lingkungan dan sosial dari aktivitas pertambangan sudah seringkali dilaporkan. Jaringan Advokasi Pertambangan (Jatam) dimana 71 kon- flik masyarakat melawan perusahaan dan pemerintah atas penolakan izin usaha pertambangan dalam rentang waktu 2014-2019, yang memperebutkan lahan seluas 925.748 ha. ${ }^{8}$ Selain itu, cukup banyak pemegang izin usaha yang tidak melakukan reklamasi pasca tambang, yang mengakibatkan pencemaran dan hilangnya nyawa.

Tulisan ini menggunakan analisis "judicial review" untuk melihat potensi pertentangan norma dalam UUMB dengan konsep PTD yang terkandung dalam Pasal 33 (3) UUD $1945 . \quad J u d i c i a l$ review diartikan oleh Jimly Asshiddiqie sebagai pengujian yang dilakukan melalui mekanisme lembaga peradilan terhadap kebenaran suatu norma. ${ }^{9}$ Dalam artikel ini, judicial review dilakukan terhadap UUMB dan keselarasannya dengan UUD 1945, khususnya menguji adanya hak konstitusional Warga Negara yang dilanggar dengan dikeluarkannya UUMB.

Artikel ini akan dibagi menjadi lima bagian. Setelah pendahuluan, bagian kedua akan dilanjutkan dengan pembahas-

\footnotetext{
${ }^{6}$ Rully M. Ramli, "Revisi UU Minerba, Ini Beberapa Pasal yang Tuai Polemik”, Kompas, 2020, $\underline{\text { htt- }}$ ps://money.kompas.com/read/2020/05/13/085813226/revisi-uu-minerba-ini-beberapa-pasal-yang-tuai-polemik, Diakses tanggal 29 Juni 2020

${ }^{7}$ Jaringan Advokasi Tambang, "Putusan Sidang Rakyat: UU Minerba Harus Batal - JATAM”, Jatam, 1 Juni 2020, https://www.jatam.org/putusan-sidang-rakyat-uu-minerba-harus-batal-demi-hukum-untuk-keselamatan-dan-kedaulatan-rakyat/, Diakses tanggal 28 Juni. 2020.

${ }^{8}$ Hukumonline, "Jatam: Ada 71 Konflik Pertambangan Periode 2014-2019”. 7 Januari 2020, https:// www.hukumonline.com/berita/baca/lt5e14311f6aa5a/jatam--ada-71-konflik-pertambangan-periode-2014-2019/. Diakses tanggal 26 Juni. 2020.

${ }^{9}$ Nurul Qamar, "Kewenangan Judicial Review Mahkamah Konstitusi - Neliti." Jurnal Konstitusi, Vol. 1, No. 1, (2012), https:// www.neliti.com/publications/229174/kewenangan-judicial-review-mahkamah-konstitusi. Diakses tanggal 15 Juni 2020.
} 
an yang mendiskusikan esensi konsep PTD dalam hukum Amerika Serikat sebagai perbandingan. Bagian ketiga dilanjutkan dengan mendiskusikan eksistensi konsep PTD dalam hukum Indonesia. Keempat, menguji penggunaan konsep PTD untuk menganalisis konstitusionalitas UUMB. Bagian kelima akan membahas kesimpulan atas permasalahan yang dipaparkan. Penelitian ini menggunakan pendekatan yuridis-normatif, yang menggunakan sumber data sekunder berupa literatur, peraturan perundang-undangan dan putusan Mahkamah Konstitusi (MK) untuk menjawab permasalahan.

\section{PTD di Amerika Serikat}

Doktrin PTD yang berasal dari zaman romawi, bertujuan untuk melindungi ruang umum yang bebas dan dapat diakses oleh publik dengan dasar kepercayaan yang diberikan oleh lembaga negara. ${ }^{10}$ Pada perkembangannya, PTD digunakan di berbagai negara di mana konsep trust atau kepercayaan melekat tanpa diperlukan bukti perjanjian tertulis dalam hubungan negara dan masyarakat. ${ }^{11}$ Untuk lebih memahami konteks trust, maka konteks trust dalam hukum privat akan dijabarkan sebagai perbandingan. Trust pada konsep hukum privat dapat dianalogikan dengan hubungan pengelola apartemen dan penyewa dalam perjanjian sewa menyewa. Dalam hal ini, penyewa memiliki kewajiban menjaga kebersihan unit dan pengelola wajib menyediakan unit yang bersih, memperbaiki fasilitas umum yang rusak. Contoh sederhana trust tersebut menunjukkan kedua pihak harus menjaga satu objek yang sama agar dapat digunakan penyewa unit berikutnya.

Di Amerika Serikat, pengaturan PTD dicantumkan dalam konstitusi negara-negara bagian untuk melindungi dan menjaga kelestarian lingkungan. ${ }^{12}$ Terdapat setidaknya lima negara bagian yang mencantumkan PTD pada sistem pemerintahan mereka. ${ }^{13}$ Sebagian besar konstitusi negara bagian lain dan konstitusi pemerintah federal Amerika Seri-

${ }^{10}$ H. M. Babcock. "Has the U.S. Supreme Court Finally Drained the Swamp of Takings Jurisprudence? The Impacts of Lucas v. South Coastal Council on Wetlands and Coastal Barrier Beaches". Harvard Environmental Law Review, Vol. 19, 1995; lihat juga Dowie, M. "Salmon and The Caesar: Will a Doctrine from The Roman Empire Sink Ocean Aquaculture?". September October 2004. Tersedia di http:www.legalaffairs.org/issues/September-October-2004/termsofart_sepoct04.msp diakses tanggal 20 Juli 2020.

${ }^{11}$ Mary Christina Wood, "Advancing The Sovereign trust of Government to Safeguard The Environment for Present and Future Generations (Part II): Instilling A Fiduciary Obligation in Governance, Lewis \& Clark Law School ENVTL L. Vol. 39, No. 91, (2009).

${ }^{12}$ Sun, H. "Toward A New Social-Political Theory of The Public Trust Doctrine". Vermont Law Review, Vol. 565, (2011).

${ }^{13}$ Oliver A. Houck. "Why Do We Protect Endangered Species, and What Does that Say About Whether Restrictions on Private Property to Protect them Constitute "Takings?" Iowa Law Review, Vol. 80, No. 297, (1995). 
kat tidak secara eksplisit mencantumkan PTD. Pada tahun 1969 pemerintah Amerika Serikat dalam peraturan National Environmental Policy Act (NEPA) menggarisbawahi bahwa tujuan nasional adalah: "Fulfill the responsibilities of each generation as trustee of the environment for succeeding generations" ${ }^{14}$ Frasa ini menunjukkan serapan doktrin PTD dimana pemerintah memiliki tanggung jawab untuk menjaga lingkungan antar lintas generasi. Tujuan PTD untuk melindungi lingkungan yang tertuang pada NEPA merupakan produk hukum yang positif. Setelah PTD tertuang pada NEPA, beberapa negara bagian memasukan PTD dalam hukum negara bagian mereka. Hal ini memberikan dasar hukum masyarakat untuk mengajukan gugatan terhadap pemerintah atas pembiaran aktivitas komersial yang dapat merusak lingkungan.

Menurut Sagarin \& Turnipseed, PTD memiliki empat unsur utama, yaitu: 1) adanya konflik kepentingan umum dan swasta dalam pengelolaan SDA di ruang publik; 2) dapat diakses secara langsung oleh masyarakat dan digunakan sebagai sarana komersial (fishing, navigation etc) dan pariwisata (recreational activity); 3) adanya kegiatan alih fungsi SDA yang bertujuan memajukan ekonomi atau menguntungkan pihak swasta; 4) jika SDA pada ruang publik tersebut terdegradasi dan mengurangi hak akses publik, masyarakat berhak mengajukan gugatan ke pengadilan. ${ }^{15}$ Keempat elemen tersebut tidak mengikat secara kumulatif karena setiap negara bagian memiliki hukum dan interpretasi yang berbeda terhadap PTD. Selain itu, hukum federal maupun konstitusi Amerika Serikat tidak mengatur konsep PTD secara tertulis menjadi acuan hukum negara bagian.

Pada kasus Illinois Central v. Illinois, PTD dijadikan dasar untuk melarang pejabat publik memberikan sebagian besar daerah pelabuhan untuk perusahaan swasta. ${ }^{16}$ Dalam kasus ini, perusahaan kereta api Chicago Railways melayangkan gugatan kepada Pemerintah Kota Chicago dengan dalih menggagalkan proses ambil alih pelabuhan yang akan digunakan untuk perluasan rel kereta api (membongkar tiang pancang dermaga/pier). ${ }^{17}$ Pengadilan tidak mengabulkan gugatan perusahaan dengan alasan kelangsung-

${ }^{14}$ Deklarasi Kongres untuk Kebijakan Nasional Lingkungan/ Congressional Declaration of National Environmental Policy No. 42 U.S.C. § 4331 (b) (1) ), https://www.law.cornell.edu/uscode/text/42/4331. Diakses tanggal 14 Juli 2020.

${ }^{15}$ Raphael D. Sagarin \& Mary Turnipseed, “The Public Trust Doctrine: Where Ecology Meets Natural Resources Management", Annu Rev. Environ, Resour, Vol. 37, (2012). hlm. 473-74.

${ }^{16}$ Douglas Grant, "Underpinnings of the Public Trust Doctrine: Lessons from Illinois Central Railroad", Ariz. St. L. J., Vol. 33, (2018).

${ }^{17}$ District court of Illinois diputuskan di Pengadilan Tingkat Federal Amerika Serikat di Washington DC, Illinois Central R. Co. V. Illinois, 146 U.S. 433 (1892). 
an proyek tersebut dapat mengganggu hak masyarakat mencari nafkah dan juga melakukan aktivitas rekreasi, seperti memancing. ${ }^{18}$ Pada kasus tersebut, pengadilan menyatakan bahwa PTD memiliki prinsip eksklusif atas suatu hal tertentu. ${ }^{19}$ Prinsip ini menggaris bawahi jika "siapa pun tidak dapat mengubah sumber daya alam yang merupakan sumber keberlangsungan hidup banyak orang." 20 Prinsip eksklusif pada PTD dan penerapannya tersirat pada Konstitusi Amerika Serikat melalui kalimat "Intergenerational equity" atau keadilan antar generasi. ${ }^{21}$ Doktrin PTD juga menekankan publik sebagai pemilik utama sebuah properti terlepas dari tujuan pemerintah untuk mengedepankan pembangunan. Selama suatu SDA berada dalam ranah kepentingan umum, pemerintah tidak berhak mengalihkan kepemilikan properti pada pihak lain.

Penerapan doktrin PTD dapat juga dilihat pada kasus Lucas v. South Caroli$n a^{22}$ dimana pemerintah melarang Lucas membangun properti di wilayah pesisir pantai yang diperoleh dengan Hak Milik. Pemerintah berdalih pendirian properti tidak diperbolehkan di kawasan pesisir pantai karena adanya dampak lingkungan abrasi. Kejadian ini membuat Lucas mengajukan gugatan karena pemerintah mengambil alih properti yang dia miliki di pesisir pantai tanpa kompensasi. Pengadilan memutuskan bahwa terlepas dari tujuan perlindungan lingkungan dengan dasar PTD, pemerintah dapat secara konstitusional mengambil hak atas tanah dari publik dengan memberikan kompensasi. ${ }^{23}$ Kasus ini menunjukkan bahwa doktrin PTD tidak hanya membahas tentang pemenuhan ekspektasi publik atas kepemilikan (ownership) atas SDA seperti pantai dan lahan basah tetapi juga menekankan agar daerah sekitar pantai dapat memenuhi fungsi sosial dan ekologi. Pengadilan memberikan pengertian bahwa doktrin PTD secara tradisional dapat diterapkan pada objek tanah, laut, air dari sungai hingga ke danau, dan ruang terbuka publik. ${ }^{24}$

${ }^{18}$ Ibid., pada paragraf 454.

${ }^{19}$ Ibid., pada paragraf 433.

${ }^{20}$ Mary Christina Wood, Nature's Trust: Environmental Law for A New Ecological Age. (Cambridge: Cambridge University Press, 2013), hlm 310.

${ }^{21}$ Brian Leiter, Carole E. Handler \& Milton Handler, "A Reconsideration of the Relevance and Materiality of the Preamble in Constitutional Interpretation," 12 Cardozo Law Review 117 (1990) tersedia di https://chicagounbound.uchicago.edu/cgi/viewcontent.cgi?article=2568\&context= journal_articles

${ }^{22}$ Cornell Law School. Lucas. S.C. Coastal Council, 5050 U.S. 1003 (1992) tersedia di https://www. law.cornell.edu/supct/html/91-453.ZS.html

${ }^{23}$ Ibid.

${ }^{24}$ JD Kearney \& TW Merrill. "The Origins of The American Public Trust Doctrine: What Really Happened in Illinois Central", The University of Chicago Law Review, Vol. 71, (2004). 
Dalam perkembangannya, PTD juga mulai menjadi dasar hukum dalam litigasi perubahan iklim. Pada kasus Alec v. Jackson ${ }^{25}$ dan Juliana v. United States ${ }^{26}$, para penggugat melayangkan gugatan ke pemerintah federal Amerika Serikat untuk segera mempersiapkan langkah strategis penanggulangan perubahan iklim seperti pengurangan emisi Gas Rumah Kaca. Kedua kasus ini menunjukkan bahwa konsep PTD dapat diperluas implementasinya untuk menuntut kewajiban pemerintah federal mengawasi peningkatan emisi. ${ }^{27}$ Kasus ini juga memperluas penerapan doktrin PTD dengan memberikan kewajiban bagi pemerintah untuk menjaga kelestarian lingkungan lintas generasi. Pada kasus Alec v. Jackson, pengadilan memutuskan bahwa PTD dapat diterapkan, tetapi, tidak dapat mengabulkan tuntutan karena melampaui kewenangan pengadilan untuk mengatur rencana kerja pemerintah dalam menentukan target perubahan iklim. Sedangkan pada Juliana $v$. United States, pengadilan juga mengakui ekstrapolasi penerapan PTD dalam litigasi perubahan iklim. Akan tetapi, penggugat harus memenuhi elemen "Substantially Redress", yang memiliki arti bahwa kerugian ha- rus ditunjukkan secara nyata dan tidak bersifat spekulatif. Kedua kasus tersebut dengan jelas telah menunjukkan bahwa doktrin PTD dapat diterapkan pada kasus lingkungan. Tetapi, diperlukan beberapa klaim tambahan untuk mengabulkan gugatan penggugat di pengadilan.

\section{PTD dalam Sistematika Hukum In- donesia}

Menurut Butt dan Murharjanti (2019), konsep PTD dalam sistem common law dapat ditemukan dalam Pasal 33 ayat (3) Undang-Undang Dasar 1945 yaitu “Bumi dan air dan kekayaan alam yang terkandung di dalamnya dikuasai oleh negara dan dipergunakan untuk sebesarbesar kemakmuran rakyat" ${ }^{28} \mathrm{M}$. Daud Silalahi juga memahami pasal ini sebagai perwujudan PTD di Indonesia atas dasar dikuasainya sumber daya alam untuk dikelola atau digunakan untuk sebesar-besarnya kemakmuran rakyat banyak, yang memberikan kewajiban pemerintah sebagai wakil rakyat, untuk melindungi kepentingannya yang dirugikan (parens patriae principle)". ${ }^{29}$

${ }^{25}$ Pengadilan Tingkat Federal Amerika Serikat, Washington DC,. Alec L., v. Jackson 863 F. Supp. 2d 11, 12, 17 (D.D.C. 2012), aff'd sub nom. Alec. ex rel, Loorz v. McCarthy, 561. F. App'x 7. (D.C. Cir. 2014)

${ }^{26}$ Sabin Center for Climate Change Law. Op.Cit.

${ }^{27} \mathrm{Ibid}$.

${ }^{28}$ Simon Butt \& Prayekti Murhajanti. Country: Indonesia pada the Oxford Handbook of Comparative Environmental Law, edited by Emma Lees and Jorge E. Vinuales. (United Kingdom: Oxford University Press. 2019), hlm. 234.

${ }^{29}$ Daud Silalahi, Op.Cit. 
Unsur-unsur PTD dalam common law, seperti eksistensi hak publik dalam pemanfaatan SDA meskipun kepemilikan SDA diberikan kepada individu tertentu, juga dapat ditemukan dalam beberapa Undang-Undang di bidang SDA yang mengacu pada Pasal 33 UUD 1945. Misalnya, Pasal 6 UUPA mengatur bahwa tanah memiliki fungsi sosial. Artinya, seseorang tidak dapat mempergunakan tanah miliknya semata-mata untuk kepentingan pribadi, jika hal itu menimbulkan kerugian masyarakat. Pasal 58 UU No. 39/ 2014 tentang Perkebunan juga mengatur bahwa pemegang izin usaha perkebunan harus menyediakan 20\% dari areal kerja untuk perkebunan masyarakat (kebun plasma). ${ }^{30}$

Selanjutnya, berdasarkan pendapat MK, Pasal 33 UUD 1945 harus dibaca secara sistematis untuk memahami maksud dari setiap ayat. ${ }^{31}$ Penjelasannya sendiri menegaskan bahwa kemakmuran bersama lebih diutamakan daripada kemakmuran seseorang dan cabang-cabang produksi yang penting dikuasai oleh negara karena dapat menindas rakyat apabila jatuh ke tangan perorangan. $\mathrm{Pu}-$ tusan MK No. 001-021-022/PUU-I/2003 memaknai "dikuasai oleh negara" dalam arti luas, “...termasuk pula di dalamnya pengertian kepemilikan publik oleh kolektivitas rakyat, yang memberikan mandat bagi negara untuk mengadakan kebijakan (beleid) dan tindakan pengurusan (bestuursdaad), pengaturan (regelendaad), Pengelolaan (behersdaad) dan pengawasan (toezichthoudensdaan) untuk tujuan sebesar-besarnya kemakmuran rakyat." ${ }^{\prime 2}$

Putusan Mahkamah Konstitusi Nomor 21-22/ PUU-V/ 2007 juga menegaskan bahwa Pasal 33 UUD 1945 mengatur tentang

“...keterlibatan atau peran aktif negara untuk melakukan tindakan dalam rang$k a$ penghormatan (respect), perlindungan (protection) dan pemenuhan (fulfillment) hak-hak ekonomi dan sosial warga negara." 33

Kedua putusan tersebut jelas mengakui dimensi publik kepemilikan SDA yang selaras dengan konsep PTD dalam hukum Amerika Serikat, meskipun belum teruji implementasinya dalam kasus hukum. Namun, penerapan teori PTD terhadap kasus terkait eksploitasi lingkungan tetap potensial dalam hukum Indonesia. Menurut Jimly Asshiddiqie, nuansa hijau dalam hukum Indonesia terkandung dalam Pasal $28 \mathrm{H}$ dan 33 ayat

\footnotetext{
${ }^{30}$ Indonesia. Undang-Undang No. 39 Tahun 2014 tentang Perkebunan. LN No. 25 tahun 2004. TLN No. 5059.

${ }^{31}$ Putusan Mahkamah Konstitusi No. 001-021-022/PUU-I/2003, hlm. 37

${ }^{32}$ Putusan MK No. 001-021-022/PUU-I/2003, hlm. 333.

${ }^{33}$ Putusan MK No. 21-22/PUU-V/2007, hlm. 185.
} 
(4) UUD 1945, meskipun UUD 1945 masih jauh dari konsep "green constitution" yang ideal. ${ }^{34}$ Konsep PTD yang berkembang di Amerika Serikat juga pada awalnya berpegang pada prinsip hak properti dan diperluas penggunaannya dalam kasus-kasus lingkungan, seperti Juliana v. United States mengenai litigasi perubahan iklim. ${ }^{35}$

Untuk analisis lebih mendalam, UUMB akan digunakan sebagai studi kasus dalam menggunakan konsep PTD dengan pendekatan judicial review. Metode judicial review dibagi menjadi 2 model yaitu bidang pengadilan dan bidang konstitusi. ${ }^{36}$ Judicial review bidang konstitusi adalah pengujian Undang-Undang terhadap Undang-Undang Dasar yang diatur dalam Pasal 24 C UUD 1945 sebagai salah satu kewenangan Mahkamah Konstitusi, sedangkan judicial review bidang pengadilan, yaitu menguji keselarasan peraturan di bawah UU dengan UU, menjadi wewenang Mahkamah Agung. Artikel ini menekankan pendekatan judicial review bidang konstitusi, terutama aspek materielnya, karena objek yang dikaji adalah keselarasan UUMB terhadap UUD 1945. Selain itu MK memiliki yurisdiksi berdasar Pasal 51 ayat (1) UU MK, pemohon adalah pihak yang mengang- gap "hak dan/atau kewenangan konstitusionalnya" dirugikan oleh berlakunya undang-undang. Dalam hal ini, eksistensi hak WN Indonesia dalam Pasal 33 UUD 1945 terkait "hak untuk mendapatkan kemakmuran atas kekayaan alam yang dikuasai oleh negara" ${ }^{37}$

Menurut Penulis, konsep PTD dalam Pasal 33 UUD 1945 memiliki dua syarat operasional untuk menentukan apakah aturan dalam suatu UU SDA bersifat inkonstitusional atau tidak: Pertama, apakah SDA yang dimaksud termasuk dalam cabang produksi penting negara dan yang menguasai hajat hidup orang banyak sehingga harus dikuasai oleh negara yang kewenangannya diberikan oleh publik. Kedua, apakah pemerintah mempertimbangkan "sebesar-besar kemakmuran rakyat" saat melaksanakan Hak Menguasai Negara (HMN) tersebut.

Dalam putusan MK No. 001-021022/PUU-I/2003, hakim MK menggunakan syarat pertama untuk menilai apakah usaha "kelistrikan" harus dikuasai oleh negara sehingga privatisasi tenaga listrik dalam UU No. 20 Tahun 2002 tentang Tenaga Kelistrikan inkonstitusional. Hakim melihat konsiderans UU No. 20/ 2002 yang menegaskan "bahwa tenaga listrik sangat bermanfaat untuk memaju-

\footnotetext{
${ }^{34}$ Jimly Asshiddiqie. Green Constitution "Nuansa Hijau Undang-Undang Dasar Negara Republik Indonesia tahun 1945". (Jakarta: Rajawali Press, 2009).

${ }^{35}$ Sabin Center for Climate Change Law. Op.Cit.

${ }^{36}$ Nurul Qamar, Op.Cit.

${ }^{37}$ Mahkamah Konstitusi, Putusan Nomor: 001-021-022/PUU-I/2003, hlm. 217.
} 
kan kesejahteraan umum, mencerdaskan kehidupan bangsa dan meningkatkan perekonomian". ${ }^{88}$ Kalimat ini menunjukkan pemerintah sebagai regulator mengakui pentingnya tenaga listrik bagi negara dan berimplikasi pada hajat hidup orang banyak. Pendapat para ahli juga menerangkan bahwa listrik sangat penting bagi negara sebagai komoditas, infrastruktur dan sumber pendapatan yang diperlukan dalam melaksanakan tugas-tugas pembangunan. Selain itu, pelayanan publik atas kebutuhan listrik dianggap hanya kalah dengan kebutuhan makanan.

Selanjutnya, terkait syarat operasional kedua, putusan MK No. 3/ PUU-VIII/ 2010 memaknai frasa "sebesar-besar kemakmuran rakyat" terdiri atas empat unsur pokok yaitu 1) kemanfaatan sumber daya alam bagi rakyat; 2) pemerataan manfaat sumber daya alam bagi rakyat; 3)partisipasi rakyat dalam menentukan manfaat SDA; dan 4) Penghormatan terhadap rakyat secara turun-temurun dalam memanfaatkan SDA. ${ }^{39}$

Pada kasus ini, pemohon mengajukan gugatan bahwa Hak Pengusahaan Perairan Pesisir (HP-3) diatur dalam UU No. 27 tahun 2007 tentang Pengelolaan Wilayah Pesisir dan Pulau-pulau Kecil mengurangi esensi Hak Menguasai Negara $(\mathrm{HMN})$ atas wilayah Pesisir sebagai cabang-cabang produksi penting. Konsep HP-3 sebagai "hak" dan bukan sebagai "izin" berpotensi menyebabkan HP-3 dipindah tangankan sehingga menghilangkan wewenang negara dalam mengelola wilayah pesisir.

Pada intinya, pemberian HP-3 tidak memenuhi keempat unsur tersebut karena dianggap lebih menguntungkan swasta dan perorangan yang memiliki modal besar dan akses teknologi, berpotensi menghilangkan mata pencaharian para nelayan, berkurangnya partisipasi masyarakat karena kontrol pemegang HP-3 pada kawasan pesisir dan hilangnya hak-hak tradisional masyarakat karena pemberian ganti rugi hanya akan dinikmati sebagian masyarakat.

\section{Pengujian Konsep PTD dalam UUMB}

Sebagaimana didiskusikan pada bab sebelumnya, maka dua syarat operasional PTD akan digunakan untuk mengkaji UUMB. Tes pertama digunakan untuk meninjau apakah UUMB termasuk "cabang produksi penting bagi negara dan menguasai hajat hidup orang banyak". Sebagaimana pertimbangan hakim dalam putusan MK No. 001-021-022/PUU-I/2003 dalam menentukan apakah suatu SDA termasuk cabang penting, maka pertama-tama konsiderans suatu UU SDA

\footnotetext{
${ }^{38}$ Ibid., hlm. 345.

${ }^{39}$ Mahkamah Konstitusi, Putusan No. 3/ PUU-VIII/ 2010, hlm. 157.
} 
harus dilihat terlebih dahulu. Konsiderans bagian a pada UUMB menegaskan bahwa minerba dan batu bara "memiliki peranan penting dan memenuhi hajat hidup orang banyak". Adanya bentuk pengakuan dari pembuat UU menjadi penting karena membantu hakim dalam merumuskan pertimbangannya mengenai pemenuhan syarat pertama PTD.
Selanjutnya, syarat kedua mengenai "sebesar-besar kemakmuran rakyat" akan digunakan untuk menganalisa beberapa pasal dalam UUMB yang berkaitan dengan eksploitasi lingkungan. Penulis memilih untuk membahas Pasal 22, Pasal 169 A ayat (1) dan Pasal 169 B ayat 5 UUMB.

\section{Tabel 1}

Analisa PTD atas Pasal 22 (b) dan (d); dan Pasal 169 huruf (a) dan (b) UUMB

\begin{tabular}{|c|c|c|c|c|c|}
\hline \multirow[t]{2}{*}{$\begin{array}{l}\text { Nomor } \\
\text { Pasal }\end{array}$} & \multirow[t]{2}{*}{$\begin{array}{l}\text { Pokok Perubahan Sub- } \\
\text { stansi }\end{array}$} & \multicolumn{4}{|c|}{$\begin{array}{l}\text { Pemenuhan terhadap unsur "sebesar-besar kemakmuran rak- } \\
\text { yat" }\end{array}$} \\
\hline & & $\begin{array}{l}\text { Kemanfaatan } \\
\text { sumber daya } \\
\text { alam bagi } \\
\text { rakyat }\end{array}$ & $\begin{array}{l}\text { Pemerata- } \\
\text { an manfaat } \\
\text { sumber daya } \\
\text { alam bagi } \\
\text { rakyat }\end{array}$ & $\begin{array}{l}\text { Partisipasi } \\
\text { rakyat dalam } \\
\text { menentukan } \\
\text { manfaat SDA }\end{array}$ & $\begin{array}{l}\text { Penghormat- } \\
\text { an terhadap } \\
\text { rakyat secara } \\
\text { turun-temu- } \\
\text { run dalam } \\
\text { memanfaat- } \\
\text { kan SDA }\end{array}$ \\
\hline $\begin{array}{l}22 \text { huruf b) } \\
\text { dan d) (pa- } \\
\text { sal lama) }\end{array}$ & $\begin{array}{l}\text { Mengubah luas maksi- } \\
\text { mal Wilayah pertam- } \\
\text { bangan Rakyat (WPR) } \\
\text { menjadi } 100 \text { (seratus) } \\
\text { hektare dan kedalaman } \\
\text { penggalian maksimal } \\
\text { menjadi } 100 \text { m. Sebelum- } \\
\text { nya, UU Minerba Lama } \\
\text { mengatur luas maksimal } \\
\text { WPR hanya } 25 \text { ha dan } \\
\text { kedalaman maksimal } \\
\text { hanya } 25 \text { m. }\end{array}$ & $\begin{array}{l}\text { Tidak ada, } \\
\text { karena fak- } \\
\text { tanya per- } \\
\text { tambangan } \\
\text { rakyat juga } \\
\text { mayoritas } \\
\text { dikuasai oleh } \\
\text { pihak swasta } \\
\text { yang mem- } \\
\text { perkerjakan } \\
\text { atau menga- } \\
\text { tasnamakan } \\
\text { rakyat kecil. }{ }^{40}\end{array}$ & $\begin{array}{l}\text { Tidak ada, } \\
\text { karena peme- } \\
\text { rintah belum } \\
\text { menyelesai- } \\
\text { kan per- } \\
\text { masalahan } \\
\text { pertambang- } \\
\text { an rakyat, } \\
\text { sebagian } \\
\text { besar masih } \\
\text { dikuasai } \\
\text { cukong. }\end{array}$ & \begin{tabular}{|l|} 
Tidak ada, \\
karena Peme- \\
rintah belum \\
memperbaiki \\
tata kelola \\
pertambang- \\
an rakyat se- \\
cara partisi- \\
patif sebelum \\
menentukan \\
penambahan \\
luas WPR \\
dan kedalam- \\
an.
\end{tabular} & $\begin{array}{l}\text { Tidak ada, } \\
\text { karena perlu- } \\
\text { asan wilayah } \\
\text { dan penam- } \\
\text { bahan keda- } \\
\text { laman dapat } \\
\text { mengancam } \\
\text { hak-hak ma- } \\
\text { syarakat tra- } \\
\text { disional yang } \\
\text { ada di sekitar } \\
\text { tambang. }\end{array}$ \\
\hline
\end{tabular}

${ }^{40}$ Athika Rahma, “Cegah Penyalahgunaan aturan Pertambangan Rakyat Harus Diperketat”, Liputan 6, 29 April 2020, https://www.liputan6.com/bisnis/read/4241146/cegah-penyalahgunaan-aturan-pertambangan-rakyat-harus-diperketat. Diakses tanggal 18 September 2020.

${ }^{41}$ Bahtiar Rifai, "Pemprov Banten Sebut Cukong. Tambang Emas Ilegal Kabur", Detik News 7 Februari 2020. tersedia https://news.detik.com/berita/d-4890039/pemprov-banten-sebut-cukong-tambang-emas-ilegal-kabur-dari-lebak.diakses tanggal Diakses tanggal 31 Juli. 2020.

${ }^{42}$ Ermy Ardhyanti, "Anomali Konflik Pertambangan dan Pemenuhan Hak-Hak Masyarakat Adat di Indonesia". Artice33, 9 Juni 2014, http://article33.or.id/id/opini/anomali-konflik-pertambangan- 


\begin{tabular}{|c|c|c|c|c|c|}
\hline $\begin{array}{l}169 \text { A ayat } \\
\text { (1) dan } 169 \\
\text { B ayat (5) } \\
\text { (tambahan } \\
\text { pasal baru) }\end{array}$ & $\begin{array}{l}\text { KK dan PKP2B dibe- } \\
\text { rikan jaminan per- } \\
\text { panjangan menjadi } \\
\text { IUPK dengan keten- } \\
\text { tuan: } 1 \text { ) untuk KK/ } \\
\text { PKP2B yang belum } \\
\text { memperoleh perpan- } \\
\text { jangan dijamin men- } \\
\text { dapatkan dua kali } \\
\text { perpanjangan dalam } \\
\text { bentuk IUPK untuk } \\
\text { jangka waktu paling } \\
\text { lama 10 tahun setelah } \\
\text { berakhirnya KK } \\
\text { atau PKP2B dengan } \\
\text { mempertimbangkan } \\
\text { upaya peningkatan } \\
\text { penerimaan negara; } \\
\text { 2) untuk KK/ PKP2B } \\
\text { yang telah memper- } \\
\text { oleh perpanjangan } \\
\text { pertama dijamin } \\
\text { untuk diberikan } \\
\text { perpanjangan kedua } \\
\text { dalam bentuk IUPK } \\
\text { untuk jangka waktu } \\
\text { paling lama 10 tahun } \\
\text { setelah berakhirnya } \\
\text { KK atau PKP2B } \\
\text { dengan memper- } \\
\text { timbangkan upaya } \\
\text { peningkatan peneri- } \\
\text { maan negara. } \\
\text { Pemegang KK } \\
\text { dan PKP2B dalam } \\
\text { mengajukan permo- } \\
\text { honan IUPK sebagai } \\
\text { Kelanjutan Operasi } \\
\text { Kontrak/ Perjanjian } \\
\text { dapat mengajukan } \\
\text { permohonan wila- } \\
\text { yah di luar WIUPK } \\
\text { untuk tahap kegiatan } \\
\text { Operasi Produksi ke- } \\
\text { pada Menteri untuk } \\
\text { menunjang kegiatan } \\
\text { Usaha Pertambang- } \\
\text { annya. }\end{array}$ & $\begin{array}{l}\text { Tidak ada, } \\
\text { karena } \\
\text { pemberian } \\
\text { jaminan } \\
\text { perpanjangan } \\
\text { hanya mem- } \\
\text { pertimbang- } \\
\text { kan “upaya } \\
\text { peningkatan } \\
\text { penerimaan } \\
\text { negara" dan } \\
\text { tidak menye- } \\
\text { butkan aspek } \\
\text { kesejahteraan } \\
\text { sosial dan } \\
\text { lingkungan }\end{array}$ & $\begin{array}{l}\text { Tidak ada, } \\
\text { KK dan } \\
\text { PKP2B hanya } \\
\text { diberikan ke- } \\
\text { pada konsesi } \\
\text { besar dan } \\
\text { pertimbang- } \\
\text { an kepen- } \\
\text { tingan rakyat } \\
\text { kecil tidak } \\
\text { disebutkan }\end{array}$ & $\begin{array}{l}\text { Tidak ada, } \\
\text { tidak di- } \\
\text { sebutkan } \\
\text { keterlibatan } \\
\text { rakyat dalam } \\
\text { keputusan } \\
\text { pemberian } \\
\text { (Pasal 169 A) } \\
\text { ataupun per- } \\
\text { luasan IUPK } \\
\text { (Pasal 169 B) }\end{array}$ & $\begin{array}{l}\text { Tidak ada, } \\
\text { pemberi- } \\
\text { an KK dan } \\
\text { PKP2B secara } \\
\text { logis hanya } \\
\text { mengun- } \\
\text { tungkan } \\
\text { konsesi-kon- } \\
\text { sesi besar. } \\
\text { Pertimbang- } \\
\text { an terkait } \\
\text { konflik lahan } \\
\text { sebagai dasar } \\
\text { pemberian } \\
\text { IUPK juga ti- } \\
\text { dak disebut- } \\
\text { kan; perluas- } \\
\text { an wilayah } \\
\text { kerja dapat } \\
\text { mengancam } \\
\text { wilayah adat } \\
\text { masyara- } \\
\text { kat sekitar } \\
\text { tambang. } \\
\text { Pertimbang- } \\
\text { an terkait } \\
\text { konflik lahan } \\
\text { sebagai dasar } \\
\text { perluasan } \\
\text { IUPK juga } \\
\text { tidak dise- } \\
\text { butkan }\end{array}$ \\
\hline
\end{tabular}

-dan-pemenuhan-hak-hak-masyarakat-adat-di-indonesia/ diakses tanggal 17 September 2020; Lihat juga Wahyu Chandra, "Masyarakat Adat Seko terancam Tambang dan Pembangunan Infrastruktur", Mongabay, 13 Maret 2016, Tersedia di https://www.mongabay.co.id/2016/03/13/masyarakat-adat-seko-terancam-tambang-dan-pembangunan-infrastruktur/ diakses tanggal 17 September 2020. 
Pasal 22 mengatur perubahan luas WPR menjadi 100 hektare dan 100-meter untuk kedalaman penggalian maksimal. Pemerintah seharusnya lebih bijak dengan memperbaiki terlebih dahulu tata kelola pertambangan skala kecil yang kecil. Dalam praktiknya, pertambangan rakyat tidak menyelesaikan masalah ekonomi karena masyarakat kerap menjadi buruh tambang tanpa izin dan diminta melakukan setoran ke cukong. Dikhawatirkan, perluasan wilayah dan kedalaman terkait WPR sangat rentan terhadap dikeluarkannya izin tambang untuk orang yang tidak semestinya. ${ }^{43} \mathrm{Hal}$ ini bertentangan dengan konsep PTD dimana seharusnya pemerintah sebagai wali (trustee) adalah pihak yang seharusnya menjaga bukan membiarkan pihak swasta melakukan kegiatan komersial yang dapat berdampak buruk pada lingkungan.

Pasal 169 A dan B memberikan keleluasaan yang begitu besar kepada pihak swasta yang masih memegang KK dan PKP2B untuk melanjutkan usahanya de- ngan rezim izin. Kedua pasal tersebut tidak menyebutkan dasar pertimbangan aspek lingkungan dan sosial yang dilindungi berdasarkan konsep PTD dalam Pasal 33 UUD 1945. Apabila hanya penerimaan negara yang menjadi pertimbangan, maka dapat dipastikan hampir seluruh pemilik KK dan PKP2B mendapatkan kepastian kelanjutan usaha karena besarnya pendapatan negara dari sektor pertambangan. Pada tahun 2019 saja, realisasi PNBP dari sektor pertambangan mencapai Rp 172 triliun. ${ }^{44}$

Dalam beberapa kasus MK, Pasal 33 UUD 1945 menjadi instrumen utama untuk menguji beberapa UU SDA yang dianggap berpihak pada pihak swasta. Pada tahun 2010, Pasal 52 ayat (1) UU Minerba Lama (UU 4/2009) yang mengatur luas minimum-maksimum (5000 ha - 100.000 ha) izin IUP eksplorasi, diujikan materinya karena dianggap menguntungkan pihak tertentu (PT Timah Tbk) yang sudah menguasai sekitar 400.000 ha Kuasa Pertambangan di Provinsi Bangka Belitung. ${ }^{45}$ Aturan minimum seluas 5000

${ }^{43}$ Della Syahni, "Menyoal UU Minerba Baru, Khawatir Makin Susahkan Warga”, Mongabay, 2020, https://www.mongabay.co.id/2020/06/27/menyoal-uu-minerba-baru-khawatir-makin-susahkan-warga/Diakses tanggal 2 Agustus 2020; Lihat Mongabay. "Wilayah Pertambangan Rakyat Digadang Jalan Keluar PETI". 22 May 2018. Tersedia di https://www.mongabay.co.id/2018/05/22/wilayah-pertambangan-rakyat-digadang-jalan-keluar-peti-nyatanya/. Diakses tanggal 31 Juli 2020; Lihat "Polres Bogor Bekuk Penambang Emas Ilegal di Cigudeg - RRI." tersedia, https://rri.co.id/polhukam/sigap/770689/polres-bogor-bekuk-penambang-emas-ilegal-di-cigudeg. Diakses 2 Agustus. 2020; Lihat juga Priantoro Yuwono, Djaja Rasji B \& Bungas Gazali N, "Penegakan Hukum Pertambangan Tanpa Izin Serta Dampaknya Terhadap Konservasi Fungsi Lingkungan Hidup". Jurnal Bina Hukum Lingkungan, Vol. 4, (2019), Hlm 7

${ }^{44}$ Pebrianto Eko Wicaksono. "Sektor Energi dan Pertambangan Setor PNBP Ro 172 triliun". 9 January 2020. Tersedia di https://www.liputan6.com/bisnis/read/4152244/sektor-energi-dan-pertambangan-setor-pnbp-rp-172-triliun diakses tanggal 25 Juli 2020

${ }^{45}$ Mahkamah Konstitusi, Putusan Nomor: 25/ PUU-VIII/ 2010, hlm. 5. 
ha secara relatif tidak akan dapat dipenuhi oleh pertambangan rakyat kecil.

Meskipun pemerintah menggunakan aspek daya tampung lingkungan hidup sebagai dasar penentuan luas minimal IUP eksplorasi, MK mengabulkan permohonan uji materiil karena UU 4/2009 tidak mengatur lebih lanjut mengenai aspek kecukupan lahan yang berpengaruh pada daya dukung dan daya tampung lingkungan hidup. Hakim memiliki pertimbangan bahwa rakyat Indonesia memberikan amanat kepada negara untuk dapat mengelola SDA untuk kemakmuran rakyat, yang diwujudkan melalui pemberian prioritas pengusahaan pertambangan mineral dan batubara kepada rakyat ekonomi kecil dan ekonomi menengah. ${ }^{46}$

Dalam UUMB, pasal 169 A dan B dapat dikatakan menguntungkan beberapa pihak karena ada sekitar delapan perusahaan tambang besar yang KK dan PKP2Bnya akan habis dalam waktu dekat (2020-2021). ${ }^{47}$ Guru besar IPB, Hariadi Kartodihardjo berpendapat bahwa pengaturan SDA di Indonesia sangat ra- wan akan state capture, ${ }^{48}$ yaitu masuknya kepentingan pihak tertentu yang di akomodasi oleh peraturan tertentu. ${ }^{49}$ Argumen ini tidak bermaksud menuduh pemerintah maupun pihak tertentu karena permasalahan state capture tidak relevan dengan implementasi PTD dan MK sendiri tidak memiliki kewenangan untuk mengadili isu ini. Akan tetapi, pembuat UUMB seharusnya lebih sensitif terhadap kesejahteraan sosial dengan mempertimbangkan konsistensi norma yang juga berasal dari putusan MK pada UU Minerba Lama.

Perlu dicatat, putusan MK terkadang tidak konsisten dan memberi keberpihakan bagi investor dalam menjalankan usaha eksploitasi SDA. Misal, kasus Tambang Hutan Lindung mengenai pengujian terhadap Pasal 83A UU No. 19/2004, yang intinya memperbolehkan adanya penambangan terbuka di kawasan hutan lindung. ${ }^{50}$ Meskipun MK mengakui adanya hak terhadap lingkungan yang sehat dan dampak tambang terhadap lingkungan, gugatan tersebut ditolak dengan alasan bahwa tataran norma yang diatur

\footnotetext{
${ }^{46}$ Mahkamah Konstitusi, Putusan Nomor: 25/ PUU-VIII/ 2010, hlm. 97

${ }^{47}$ Totok Dwi Antoro, "Pertaruhan Nasib Lingkungan oleh Revisi UU Minerba", dipresentasikan pada acara Webinar Serial Omnibus Law "Kala Lingkungan dilelang: Harga Mahal Untuk Masa Depan Lingkungan Indonesi", 20 Mei 2020, Fakultas Hukum UGM.

${ }^{48}$ Rakyat Merdeka. "State Capture Banyak Terjadi di Sektor Sumber Daya Alam". 16 Juli 2019, https://rmco.id/baca-berita/nasional/13550/state-capture-banyak-terjadi-di-sektor-sumber-daya-alam, diakses tanggal 31 Juli 2020

${ }^{49}$ Hariadi Kartodihardjo. Di Balik Krisis Ekosistem: Pemikiran tentang Kehutanan dan Lingkungan Hidup. (Depok: LP3ES. 2018).

${ }^{50}$ Simon Butt \& Prayekti Murhajanti. Loc.Cit., hlm. 250.
} 
dalam Pasal 83 A merupakan norma abstrak yang sifatnya menjalankan (eksekutif), yaitu penunjukan pejabat tertentu, dalam hal ini Presiden, yang diberi kewenangan memberikan izin dengan Keputusan Presiden. ${ }^{51}$ Padahal setelah dikeluarkan UU No. 19/ 2004, Presiden Megawati mengeluarkan Keppres yang berisi tentang daftar 13 perusahaan yang konsesi pertambangannya tumpang tindih dengan area hutan lindung, ${ }^{52}$ yang apabila diperdebatkan mengandung norma individual konkret.

\section{Penutup}

Teori PTD merupakan konsep romawi dalam pengelolaan SDA yang memberikan kewajiban negara sebagai "wali" dalam mengelola SDA untuk kepentingan publik. Studi ini membahas lebih dalam implementasi PTD dengan mengambil pemikiran sistem hukum di Amerika Serikat. Terdapat empat unsur PTD yang dapat dilihat dari beberapa kasus di Amerika Serikat diantaranya: adanya konflik kepentingan umum dan swasta dalam pengelolaan SDA di ruang publik; adanya SDA yang dapat diakses tanggal oleh masyarakat dan digunakan sebagai sarana komersial (fishing, navigation etc) dan hiburan (Recreational Activity) atau kegiatan untuk menikmati alam; adanya kegiatan alih fungsi lahan yang bertujuan untuk memajukan ekonomi atau menguntungkan pihak swasta; jika SDA pada ruang publik tersebut terdegradasi dan mengurangi hak akses publik, masyarakat berhak mengajukan gugatan ke pengadilan. Dalam perkembangannya, PTD mulai diakui penerapannya pada kasus perubahan iklim dengan beberapa batasan terkait kewenangan pengadilan dalam mengatur kebijakan pemerintah (kasus Alec) dan pembuktian kerugian yang tidak bersifat spekulatif (kasus $J u$ liana $v$ United States).

Dalam sistem hukum Indonesia, PTD hadir dalam Pasal 33 ayat (3) UUD 1945. Dalam konteks judicial review bidang konstitusi, terdapat dua syarat operasional untuk menggunakan PTD: Pertama, apakah SDA yang dimaksud termasuk dalam "cabang produksi yang penting bagi negara dan yang menguasai hajat hidup orang banyak". Kedua, apakah pemerintah mempertimbangkan "sebesar-besar kemakmuran rakyat" saat melaksanakan Hak Menguasai Negara (HMN).

Dalam konsiderans UUMB, peranan penting Mineral dan Batubara sudah sangat jelas disebutkan oleh pembuat UU sehingga syarat pertama aplikasi teori

${ }^{51}$ Mahkamah Konstitusi, Putusan Nomor 003/PUU-III/ 2005.

${ }^{52}$ Bisnis Tempo. "Pemerintah terbitkan perpu izin tambang di hutan lindung". 11 Maret 2004. Tersedia di https:/ / bisnis.tempo.co/read/40569/ pemerintah-terbitkan-perpu-izin-tambang-di-hutan-lindung diakses tanggal 31 Juli 2020 
PTD sudah terpenuhi. Selanjutnya, unsur-unsur "sebesar-besar kemakmuran rakyat" diujikan terhadap Pasal 22 huruf d, 169A ayat (1) dan 169B ayat (5) dalam UUMB. Hasil analisis dalam tabel 1 menunjukkan bahwa ketiga pasal ini tidak sesuai dengan konsep PTD karena tidak memenuhi aspek kemanfaatan sumber daya alam bagi rakyat, Pemerataan manfaat sumber daya alam bagi rakyat, Partisipasi rakyat dalam menentukan manfaat SDA dan Penghormatan terhadap rakyat secara turun-temurun dalam memanfaatkan SDA.

Meskipun menggunakan pendekatan judicial review bidang konstitusi, analisis ini tidak bermaksud membatasi penggunaan konsep PTD dalam kasus lingkungan hidup di pengadilan umum. Akan tetapi, menurut Penulis, penggunaan konsep PTD dalam kasus lingkungan pada peradilan umum harus didahului dengan pengaturan instrumen PTD pada UU 32/ 2009 tentang Lingkungan Hidup atau UU SDA lain yang berkaitan. Apabila UU terkait tidak mengadopsi konsep PTD ini, kecil kemungkinan konsep ini diterapkan di Indonesia mengingat sistem hukum Indonesia yang memiliki ciri khas peraturan tertulis (written law). 


\section{DAFTAR PUSTAKA}

\section{Peraturan Perundang-undangan}

Indonesia. UUD 1945 Republik Indonesia, tersedia di_https://jdih.pom.go.id/ uud1945.pdf

Undang-Undang No. 39 Tahun

2014 tentang Perkebunan. LN No. 25 tahun 2004. TLN No. 5059.

\section{Dokumen Internasional}

Deklarasi Kongres untuk Kebijakan Nasional Lingkungan/ Congressional Declaration of National Environmental Policy No. 42 U.S.C. § 4331 (b) (1) tersedia https://www.law.cornell. edu/uscode/text/42/4331.

\section{Putusan Pengadilan}

District court of Illinois diputuskan di Pengadilan Tingkat Federal Amerika Serikat di Washington DC, Illinois Central R. Co. V. Illinois, 146 U.S. 433 (1892)

District Court Oregon diputuskan di Pengadilan Tinggi California ( $9^{\text {th }}$ Circuit), Juliana v. United States, 217 F. Supp. 3d 1224 (D. Or. 2016)

Mahkamah Konstitusi Republik Indonesia, Putusan Mahkamah Konstitusi Republik Indonesia No. 001-021-022/ PUU-I/2003.

Putusan Mah-

kamah Konstitusi No. 001-021-022/ PUU-I/2003.

Putusan Mah-

kamah Konstitusi No. 003/PUU-III/2005.
. Putusan Mahka-

mah Konstitusi K No. 021-22/PUU$-\mathrm{V} / 2007$.

mah Konstitusi No. 003/ PUU-VIII/ 2010.

Pengadilan Tingkat Federal Amerika Serikat, Washington DC,. Alec L., v. Jackson 863 F. Supp. 2d 11, 12, 17 (D.D.C. 2012), aff'd sub nom. Alec. ex rel, Loorz v. McCarthy, 561. F. App'x 7. (D.C. Cir. 2014).

\section{Buku}

Asshiddiqie, Jimly. Green Constitution "Nuansa Hijau Undang-Undang Dasar Negara Republik Indonesia tahun 1945". Rajawali Press. 2009

Butt, Simon \& Prayekti Murhajanti. "Country: Indonesia" in the Oxford Handbook of Comparative Environmental Law, edited by Emma Lees and Jorge E. Vinuales. United Kingdom, Oxford University Press. 2019.

Kartodihardjo, Hariadi. Di Balik Krisis Ekosistem: Pemikiran tentang Kehutanan dan Lingkungan Hidup. Depok: LP3ES. 2018.

Silalahi, M. Daud. Pengaturan Hukum Sumber Daya Air dan Lingkungan Hidup di Indonesia. Bandung: Alumni. 2002

Wood, Mary Christina. Nature's Trust: Environmental Law for A New Ecological Age. Cambridge University Press. 2013. 


\section{Artikel Jurnal}

Babcock, H. M. "Has the U.S. Supreme Court Finally Drained the Swamp of Takings Jurisprudence? The Impacts of Lucas v. South Coastal Council on Wetlands and Coastal Barrier Beaches". Harvard Environmental Law Review, Vol. 19. 1995

D. Sagarin, Raphael \& Mary Turnipseed, The Public Trust Doctrine: Where Ecology Meets Natural Resources Management. Annu Rev. Environ, Resour, vol. 37. 2012.

Frank, Richard. "The Public Trust Doctrine: Assessing Its Recent Past \& Charting Its Future in UC Davis Law Review. Vol 45. 2012

Grant, Douglas. "Underpinnings of the Public Trust Doctrine: Lessons from Illinois Central Railroad", Ariz. St. L. J., Vol. 33. 2018.

Houck, Oliver A.. "Why Do We Protect Endangered Species, and What Does that Say About Whether Restrictions on Private Property to Protect them Constitute "Takings?" Iowa L.Rev., Vol. 80, No. 297. 1995.

Kearney, JD \& TW Merrill. “The Origins of The American Public Trust Doctrine: What Really Happened in Illinois Central". The University of Chicago Law Review, Vol. 71, 2004.

Leiter, Brian, Carole E. Handler \& Milton Handler, "A Reconsideration of the Relevance and Materiality of the Preamble in Constitutional Interpretation," 12 Cardozo Law Review 117 (1990) tersedia di https://chicagoun- bound.uchicago.edu/cgi/viewcontent.cgi? article $=2568 \&$ context $=$ jour$\underline{\text { nal articles }}$

Qamar, Nurul. “Kewenangan Judicial Review Mahkamah Konstitusi - Neliti." Jurnal Konstitusi, Vol.1, No.1, November 2012. Tersedia di https://www. neliti.com/publications/229174/ kewenangan-judicial-review-mahkamah-konstitusi. Diakses tanggal 15 Juni 2020.

Sun, H. "Toward A New Social-Political Theory of The Public Trust Doctrine". Vermont Law Review. Vol 565. 2011.

Wood, Mary Christina. "Advancing The Sovereign trust of Government to Safeguard The Environment for Present and Future Generations (Part II): Instilling A Fiduciary Obligation in Governance, Lewis \& Clark Law School ENVTL L. Vol. 39, No. 91. 2009.

Yuwono, Priantoro Djaja, B, Rasji \& Bungas Gazali N. "Penegakan Hukum Pertambangan Tanpa Izin Serta Dampaknya Terhadap Konservasi Fungsi Lingkungan Hidup". Jurnal Bina Hukum Lingkungan, Vol. 4, Oktober 2019.

\section{Internet}

Article 33 Indonesia. "Anomali Konflik Pertambangan dan Pemenuhan Hak-Hak Masyarakat Adat di Indonesia". 9 Juni 2014. Tersedia di http:// article33.or.id/id/opini/anomali-konflik-pertambangan-dan-pemenuhan-hak-hak-masyarakat-adat-di-indonesia/ diakses tanggal 17 September 2020 
Bisnis Tempo. "Pemerintah terbitkan perpu izin tambang di hutan lindung". 11 Maret 2004. Tersedia di https:// bisnis.tempo.co/read/40569/pemerintah-terbitkan-perpu-izin-tambang-di-hutan-lindung diakses tanggal 31 Juli 2020.

Dwi Antoro, Totok. "Pertaruhan Nasib Lingkungan oleh Revisi UU Minerba", dipresentasikan pada acara Webinar Serial Omnibus Law "Kala Lingkungan dilelang: Harga Mahal Untuk Masa Depan Lingkungan Indonesia", 20 Mei 2020, Fakultas Hukum Universitas Gadjah Mada. https:/ / www.youtube.com/watc-

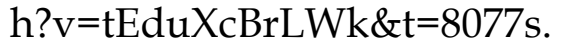

Dowie, M.. "Salmon and The Caesar: Will a Doctrine from The Roman Empire Sink Ocean Aquaculture?". September October 2004. Tersedia di https:// www.legalaffairs.org/issues/September-October-2004/termsofart sepoct04.msp diakses tanggal $20 \mathrm{Juli}$ 2020.

Eko Wicaksono, Pebrianto. “Sektor Energi dan Pertambangan Setor PNBP Ro 172 triliun". 9 January 2020. Tersedia di https://www.liputan6.com/ bisnis/read/4152244/sektor-energi-dan-pertambangan-setor-pnbp-rp-172-triliun diakses tanggal 25 Juli 2020.

Hukumonline. "Jatam: Ada 71 Konflik Pertambangan Periode 2014-2019". 7 Januari 2020. Tersedia di https:// www. hukumonline.com/berita/baca/ 1t5e14311f6aa5a/jatam-ada- -71-konflik-pertambangan-periode-2014-2019/. Diakses tanggal 26 Juni. 2020.

Jaringan Advokasi Tambang. "Putusan SidangRakyat:UU MinerbaHarus Batal - JATAM". 1 Juni 2020. Tersedia di https://www.jatam.org/2020/06/01/ putusan-sidang-rakyat-uu-minerba-harus-batal-demi-hukum-untuk-keselamatan-dan-kedaulatan-rakyat/. Diakses tanggal 28 Juni. 2020.

Mongabay. "Masyarakat Adat Seko terancam Tambang dan Pembangunan Infrastruktur".13 Maret2016 Tersedia di https://www.mongabay.co.id/ 2016/03/13/masyarakat-adat-seko-terancam-tambang-dan-pembangunan-infrastruktur/ diakses tanggal 17 September 2020.

"Kala Gubernur sampai Mahasiswa Gugat UU Minerba “. 16 January 2020. Tersedia https:// www.mongabay.co.id/2020/07/16/ kala-gubernur-sampai-mahasiswa-gugat-uu-minerba/. Diakses tanggal 18 Juli 2020.

"Wilayah Pertambangan Rakyat Digadang Jalan Keluar PETI". 22 May 2018. Tersedia di https:// www.mongabay.co.id/2018/05/22/ wilayah-pertambangan-rakyat-digadang-jalan-keluar-peti-nyatanya/. Diakses tanggal 31 Juli 2020.

Rahma, Athika “Cegah Penyalahgunaan aturan Pertambangan Rakyat Harus Diperketat". Liputan 6. 29 A pril 2020. Tersedia di https://www.liputan6. 
com/bisnis/read $/ 4241146 /$ cegah-penyalahgunaan-aturan-pertambangan-rakyat-harus-diperketat.

Ramli, Rully M. “Revisi UU Minerba, Ini Beberapa Pasal yang Tuai Polemik". Kompas. 13 May 2020. Tersedia di https://money.kompas.com/read/ 2020/05/13/085813226/revisi-uu-minerba-ini-beberapa-pasal-yang-tuai-polemik. Diakses tanggal 29 Juni 2020.

Rifai, Bahtiar. "Pemprov Banten Sebut Cukong Tambang Emas Ilegal Kabur". Detiknews. 7 Februari 2020. tersedia https://news.detik.com/ berita/d-4890039/pemprov-banten-sebut-cukong-tambang-emas-ilegal-kabur-dari-lebak.diakses tanggal Diakses tanggal 31 Juli. 2020.

RRI. "Polres Bogor Bekuk Penambang Emas Ilegal di Cigudeg - RRI". 13 Januari 2020. Tersedia di https://rri. co.id/polhukam/sigap/770689/polres-bogor-bekuk-penambang-emas-ilegal-di-cigudeg Diakses tanggal 30 Juli 2020.
Sabin Center for Climate Change Law. "Juliana v. United States - Climate Change Litigation." http://climatecasechart.com/case/juliana-v-united-states/. Diakses 1 Juli. 2020.

Solomon, C. "The Newest Legal Tool to Fight Climate Change is as Old Ancient Rome". 27 Mei 2016. Tersedia di https://www.outsideonline. com/2083441/newest-legal-tool-fight-climate-change-old-ancient-rome diakses tanggal 16 Juli 2020.

Syahni, Della. "Menyoal UU Minerba Baru, Khawatir Makin Susahkan Warga", Mongabay, 2020, https:// www.mongabay.co.id/2020/06/27/ menyoal-uu-minerba-baru-khawatir-makin-susahkan-warga/. Diakses tanggal 2 Agustus. 2020

\section{Makalah}

Cornell Law School. Lucas. S.C. Coastal Council, 5050 U.S. 1003 (1992) tersedia di https://www.law.cornell. edu/supct/html/91-453.ZS.html 